\title{
ON THE INFLUENCE OF GEOLOGICAL FACTORS UPON PLANT NUTRIENT CONTENT OF PEATS
}

\author{
MARTTI SALMI \\ The Geological Survey of Finland, Otaniemi
}

Received February 2, 1963

Attention has been given to plant nutrient content in peats in many Finnish investigations. In connection with his studies on the cultivability of bogs, KIVINEN (4) explained the chemical changes in peats arising from their botanical composition and the nutritional relations between bog plants and surface peats. The material comprised surface peats only, whose phosphorus, calcium and nitrogen contents were determined. KaILA (3) has investigated the phosphorus contents of different kinds of peat at varying depths of peat layer. In connection with research into the cultivability of soil in Finland and agrogeological mapping, MÄKITIE $(9,10$, 11), Purokoski (14), SillanpäÄ (31) and Vuorinen $(35,36,37,38)$ among others have presented results of analyses and the mean values of the plant nutrients of peat soils. These studies deal mainly with the surface parts of swamps. The elements studied were mostly copper, lead, tin, zinc, cobalt, chrome, manganese, molybdenum, nickel, and vanadium. Further data on boron, gallium and iron contents are also given.

In research work carried out by VAHTERA (34) on the nutrient content of bogs for afforestation purposes, phosphorus, potassium, calcium, magnesium and nitrogen contents were determined. Sampling did not exceed $0.6 \mathrm{~m}$ in depth and the material was treated in three depth classes.

SUNDGREN and EKMAN (33) have presented the results of an analysis of the sulphur and phosphorus contents of peats in their investigations associated with the peat industry. The subject of this paper comprises that section of these results which is taken from Aitoneva.

In his research work on peat chemical ore prospecting the author $(24,26,27$, 29) has observed the chemical composition of the entire peat layer mostly by means of sample series taken at densely-spaced sampling points and lines. Altogether 
some twenty elements were studied. Thereby it was revealed that their content in peats varies within considerable limits and that these variations are causally connected with variations in the underlying bedrock.

Recently PuUstJärvi $(18,19,20,21)$ has begun to study the use of peat as a growth bed not only for vegetables but also for flowers in greenhouses, in which peat is used as an addition to supply a varied and abundant amount of plant nutrients. Experimental cultivation has yielded promising results.

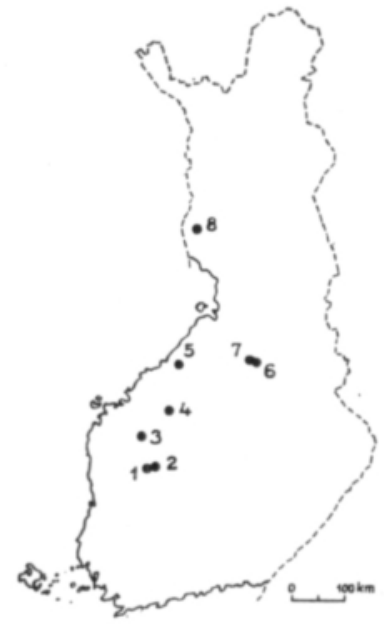

Fig. 1. The location of bogs investigated. 1. Aitoneva, 2. Lapaneva, 3. Törnävä, 4. Varkkasalonräme, 5. Susineva, 6. Malmisuo, 7. Luetsuo, 8. Riivijänkä.

Peat to be used as a growth bed is most profitably prepared as milled peat. From the bog surface a layer $1.5-2 \mathrm{~cm}$ thick is milled at one time, and depending on the drying weather 10 to 20 crops can be obtained in a summer.

The optimum crop depends mainly on the appropriateness of the fertilizers applied. It is therefore necessary to know the original plant nutrient content of the bog used as the source for the growth bed. As the manufacture of milled peat takes place along the surface and gains depth year by year, possible changes of nutrients, essential for plants, in the entire peat layer must also be known. The purpose of this study is to examine this problem as well as the correlation between geological factors such as soil and bedrock, and plant nutrient contents. Eight bogs were subjected to research. The sketch map (Fig. 1) shows their location. For purposes of comparison, the results obtained from some other bogs are refered to.

\section{Research material and methods}

The initial research material was taken from the southern part of Aitoneva in Kihniö, west of the office and laboratory buildings of Suo Oy, in the autumn of 1961, Fig. 2. This part of the bog was drained to the bottom many years ago. In places milled peat had been drawn from the area for several years; on average about one metre of peat was missing from the surface at the time when samples were taken by digging with shovels at three places, marked I, II, and III in Fig. 2. At each place four samples were taken at the following depths: 0, 0.5, 1.0 and $1.5 \mathrm{~m}$. The lowest samples were close to the bottom of the bog. 


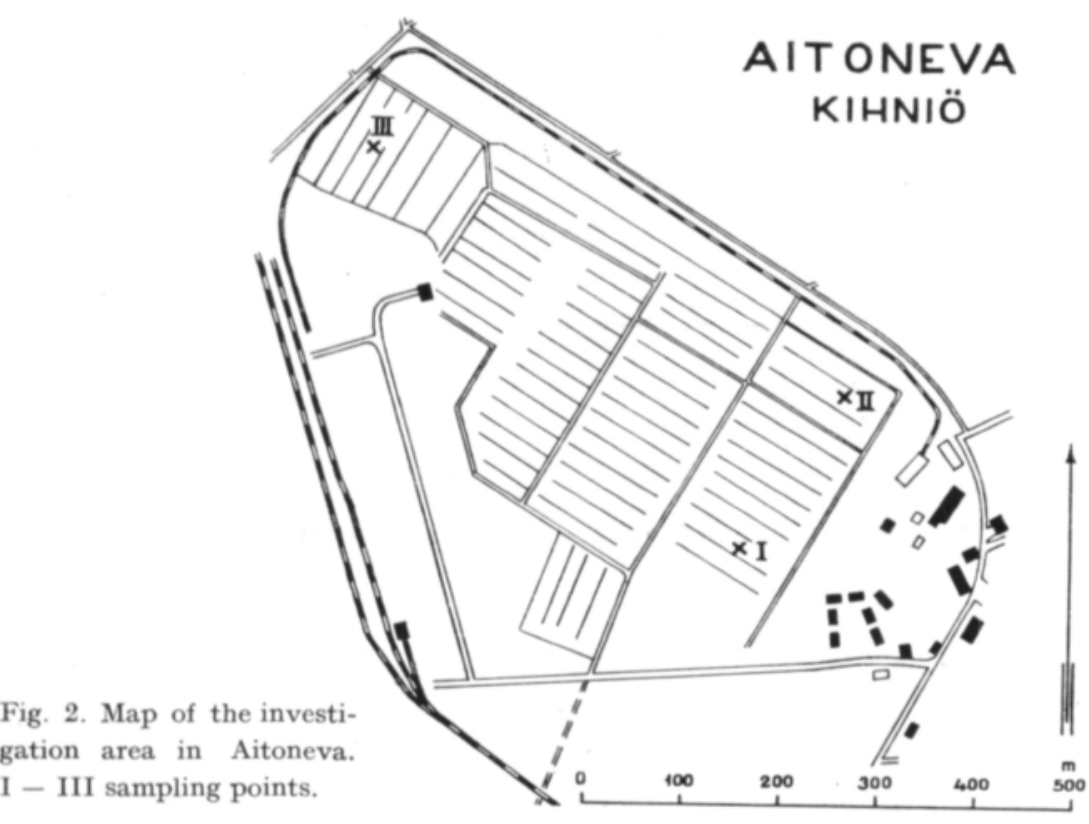

Aitoneva was chosen as a subject for study because a considerable part of the peat used in greenhouses in Finland was and is still manufactured there. The author has carried out different investigations in the area since 1942, and the bog has been used in many ways for research and experimental work associated with the peat industry; it is therefore well surveyed.

The research material was visually determined, after the peat formula of L.v. Post concerning plant material composition and the properties of the peat. The definitions of peat varieties were microscopically checked. These and other investigation results concerning the Aitoneva material are presented in Tables 1 and 2 .

Besides Aitoneva the author has at his disposal material collected from different research areas on the basis of which comparisons can be made of the variations in the plant nutrient contents of peats in varying geological conditions (Fig. 1). At many sites the nature of the bedrock could be ascertained by means of diamond drillings. The results of these investigations are shown in Tables $3-8$.

The $\mathrm{pH}$ and ash analyses of the peats were performed at the Peat Laboratory of the Department of Superficial Deposits of the Geological Survey. The pH of the peat was determined with a Beckman $\mathrm{N}$ pH meter from the inside of large samples. The material examined was therefore thus unoxidized and naturally moist. For ash determinations the samples were dried by combustion at $105^{\circ} \mathrm{C}$ and contents are given as a percentage of the dry matter.

The trace elements given in Tables 4-5 were spectrographically analysed at the laboratory of Valmet $\mathrm{Oy}$ in Jyväskylä; those in Tables 1, 2, 5, and 7 at the Chemical Department and the others at the soil laboratory of the Department of Superficial Deposits of the Geological Survey. Iron, manganese, calcium and phosphorus contents were determined colorimetrically from the peat ashes after the method of Bannerjee and Colliss (1). The sulphur contents were ascertained after König and are given as a proportion of the total dry matter of the peat. 
In Tables 1, 4, 5, and 7 the trace element values as ppm (millionth parts) of the peat ash are shown in column 1 and as ppm of the dry-matter of peat in column 2. Values can also be read in terms such as $\mathrm{mg} / \mathrm{kg}$ or $\mathrm{g} / \mathrm{t}$ of the peat ash or of the dry-matter of peat. In Table 2 manganese is given as ppm, other elements as percentages, as are the oxides in Table 3 . Values given as percentages in the first column of Table 2 can be read, e.g. Fe $=260 \mathrm{~g} / \mathrm{kg}$ or $260 \mathrm{~kg} / \mathrm{t}$ of the peat ash and in column $2 \mathrm{Fe}=8.84 \mathrm{~g} / \mathrm{kg}$ or $8.84 \mathrm{~kg} / \mathrm{t}$ of the dry-matter of peat. In Table 6 the values of phosphorus and sulphur can be considered in terms of $\mathrm{kg} / \mathrm{t}$.

Research results

Aitoneva

Peat varieties in different profiles differ distinctly from one another and thus yield comparison material for the study. Site I displays Sphagnum peats (S) with their characteristic low $\mathrm{pH}$ values $3.7-4.2$. Low ash content $-1.4-3.4 \%-$ is also peculiar to these peats. At site II S- and S-dominated peats occur. Carex (C) appears as the most important additional matter, and $\mathrm{pH}$ values, at 3.5 to 5.9 and ash contents at 0.9 to 5.5 , are higher than those at site I. At site III the peat is Carex-dominated, but in the lower part of the profile Phragmites (Phr) provide interesting additional material. The $\mathrm{pH}$ values of peats, $4.3-5.5$, lie between those in two former profiles as do the ash contents, $2.6-6.3 \%$, although the highest ash content of the entire material occurs in sample 11 of this profile.

The general feature in the ash content of peats is their tendency to decrease from the bottom towards the surface which must be considered normal. The phenomenon is not, however, as conspicuous as is the increase of acidity upwards in the peat layer.

The humification value $(\mathrm{H})$ of peats is mainly from 5 to 6 , and less only in a few cases. According to field investigations in 1942 there was an average $0.5 \mathrm{~m}$ of slightly humified ErS- and S-peat in the bog surface, removed in connection with peat harvesting, in the area in question. At site III there is $20-30 \mathrm{~cm}$ of gyttja at the bottom.

Elements presented in Table 1 occur so scantily in the specimens that they belong to the trace elements of peats. So does manganese in Table 2 .

Copper, molybdenum and boron occur in all the samples as amounts verifiable with the method used. Copper values range from 100 to $370 \mathrm{ppm}$, molybdenum from 19 to $52 \mathrm{ppm}$, and boron from 40 to $260 \mathrm{ppm}$ in peat ashes. When calculated in terms of the dry-matter of peat the values are: copper 1.6-17.6, molybdenum $0.33-2.3$ and boron $0.72-11.7 \mathrm{mg} / \mathrm{kg}$. From different layers it can be stated that molybdenum and boron contents increase markedly, and that of copper more irregularly when measured downward.

The surface samples contain less cobalt than can be measured with the analysis method used. Contents are low $-<20-75 \mathrm{ppm}$ of peat ash and $<0.23-2.21$ $\mathrm{mg} / \mathrm{kg}$ of dry peat, - and decrease distinctly from the bottom upwards. This is also seen in the average conditions in different layers.

Zinc contents verifiable by the method of analysis used are met with in surface samples only. Their occurrence in Aitoneva as elsewhere is quite capricious. 


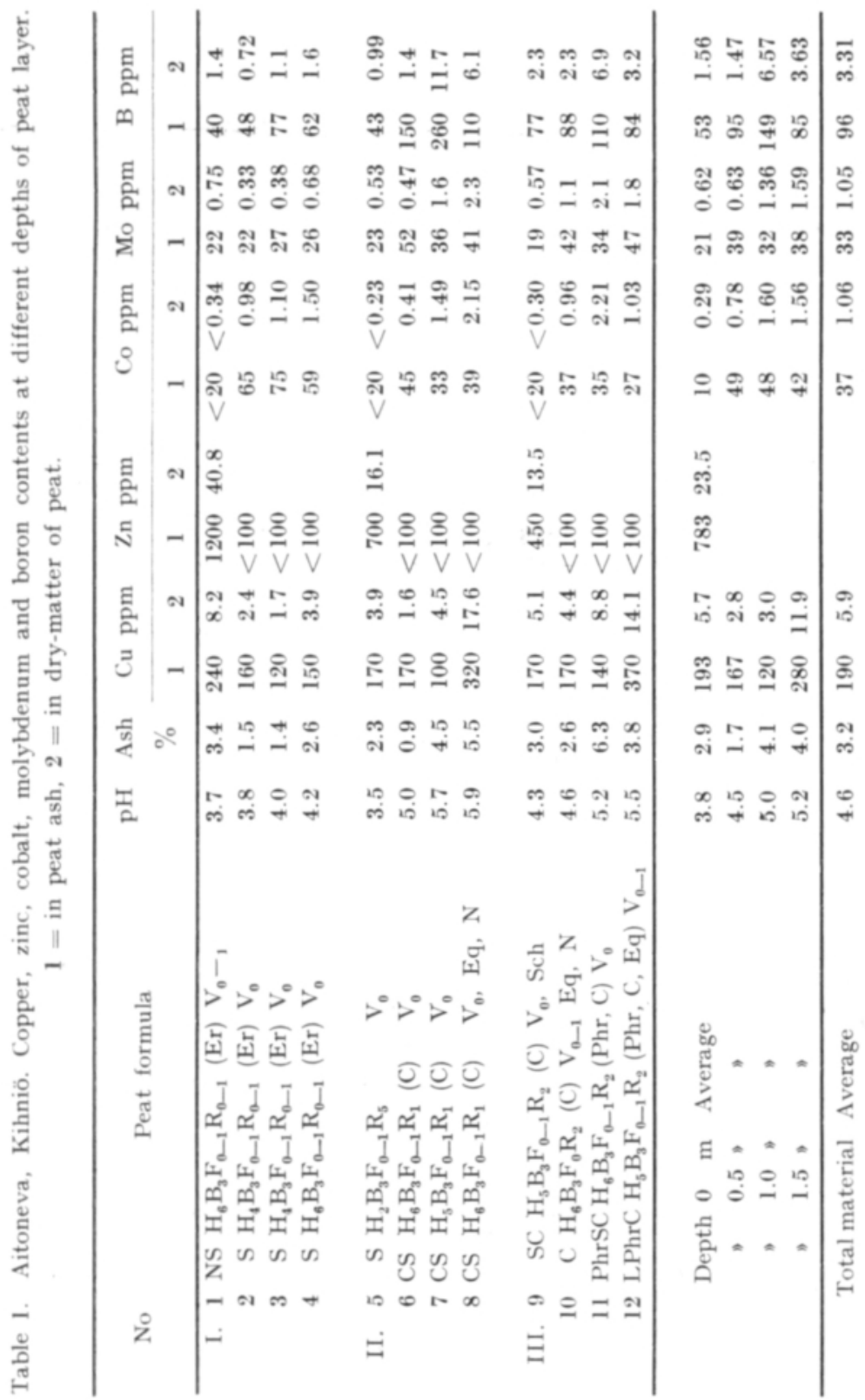


Table 2. Aitoneva, Kihniö. Iron, manganese, calcium, phosphorus and sulphur content of peats. $1=$ in peat ash, $2=$ in dry-matter of peat.

\begin{tabular}{|c|c|c|c|c|c|c|c|c|c|c|c|}
\hline \multirow{2}{*}{\multicolumn{3}{|c|}{$\begin{array}{l}\text { Sampling point } \\
\text { and } \\
\text { sample number }\end{array}$}} & \multicolumn{2}{|c|}{$\mathrm{Fe} \%$} & \multicolumn{2}{|c|}{ Mn ppm } & \multicolumn{2}{|c|}{$\mathrm{Ca} \%$} & \multicolumn{2}{|c|}{ P \% } & \multirow{2}{*}{$\begin{array}{c}\mathrm{S} \% \\
2 \\
\end{array}$} \\
\hline & & & 1 & 2 & 1 & 2 & 1 & 2 & 1 & 2 & \\
\hline \multirow[t]{4}{*}{ I } & 1 & & 26.0 & 0.884 & 350 & 120 & 8.78 & 0.299 & 2.013 & 0.068 & 0.21 \\
\hline & 2 & & 11.1 & 0.169 & 500 & 8 & 20.45 & 0.311 & 1.277 & 0.019 & 0.12 \\
\hline & 3 & & 22.9 & 0.323 & 680 & 10 & 18.38 & 0.259 & 1.344 & 0.019 & 0.16 \\
\hline & 4 & & 14.7 & 0.378 & 1860 & 48 & 14.98 & 0.385 & 1.288 & 0.033 & 0.13 \\
\hline \multirow[t]{4}{*}{ II } & 5 & & 35.6 & 0.812 & 660 & 15 & 9.17 & 0.209 & 2.598 & 0.059 & 0.20 \\
\hline & 6 & & 27.5 & 0.234 & 1560 & 13 & 12.67 & 0.108 & 1.600 & 0.014 & 0.19 \\
\hline & 7 & & 19.8 & 0.899 & 1760 & 80 & 12.84 & 0.583 & 0.794 & 0.036 & 0.44 \\
\hline & 8 & & 37.7 & 2.058 & 2000 & 109 & 19.20 & 1.048 & 0.981 & 0.054 & 0.52 \\
\hline \multirow[t]{4}{*}{ III } & 9 & & 29.4 & 0.891 & 980 & 30 & 9.87 & 0.299 & 2.187 & 0.066 & 0.51 \\
\hline & 10 & & 29.3 & 0.768 & 1480 & 39 & 11.36 & 0.298 & 1.656 & 0.043 & 0.50 \\
\hline & 11 & & 22.4 & 1.411 & 2320 & 146 & 13.72 & 0.864 & 1.275 & 0.080 & 0.54 \\
\hline & 12 & & 29.1 & 1.117 & 2480 & 95 & 10.75 & 0.413 & 1.294 & 0.050 & 0.67 \\
\hline Depth & 0 & $\mathrm{~m}$ & 30.3 & 0.862 & 660 & 19 & 10.03 & 0.375 & 2.666 & 0.064 & 0.31 \\
\hline , & 0.5 & , & 22.6 & 0.390 & 1180 & 20 & 14.83 & 0.239 & 1.511 & 0.025 & 0.27 \\
\hline , & 1.0 & v & 21.7 & 0.878 & 1590 & 79 & 14.78 & 0.569 & 1.138 & 0.045 & 0.38 \\
\hline " & 1.5 & * & 27.2 & 1.184 & 2110 & 84 & 14.78 & 0.615 & 1.188 & 0.046 & 0.44 \\
\hline \multicolumn{3}{|c|}{ Average } & 25.5 & 0.829 & 1380 & 67 & 13.61 & 0.450 & 1.526 & 0.045 & 0.47 \\
\hline
\end{tabular}

Manganese, which in Table 2 belongs to the trace elements, is more abundant in the Aitoneva peat than the elements listed above. It ranges from 350 to 2480 $\mathrm{ppm} \mathrm{Mn}$ in peat ash and from 8 to $146 \mathrm{mg} / \mathrm{kg}$ in dry peat. Contents decrease from the bottom upwards.

The Aitoneva peat ashes contain more iron than the other elements investigated. Its variations are noticeable - from 11.1 to $37.7 \%$. Maximum contents are found in the surface samples. Minimum amounts of iron are found in the dry-matter of peat below the surface samples, but values increase from there towards the bottom. It ranges from 1.69 to $20.58 \mathrm{~g} / \mathrm{kg}$ in the dry-matter of peat. S-peats contain less iron than the others, C-dominated contain the most iron of all.

Calcium also belongs to the main components of Aitoneva peat ashes, its contents ranging from 8.78 to $20.45 \%$ in ash and from 1.08 to $10.48 \mathrm{~g} / \mathrm{kg}$ in the dry-matter of peat. The mean values of different profiles show a slight increase from the surface towards the bottom.

The phosphorus content of peat ashes increases from the bottom upwards ranging from 0.79 to $2.59 \%$, both in profile II. The values in different profiles differ to some extent from each other, yet without any clear consistency. Calculated from the dry-matter content of peat, phosphorus is most abundant in the surface samples. Contents are clearly lowest in S-peats and highest in C-dominated peats. Phosphorus comprises $0.14-0.80 \mathrm{~g} / \mathrm{kg}$ of dry peat. 
Sulphur occurs least in S-peats and most abundantly in C-dominated peats. Samples 11-12 contain the highest proportions of sulphur evidently, due to Phrremnants and gyttja underlying the peat. The sample material from Aitoneva contains sulphur from 1.2 to $6.7 \mathrm{~g} / \mathrm{kg}$ of dry peat. The contents decrease downwards in profile $\mathrm{I}$, in others they increase in the same direction.

\section{Other investigation sites}

Table 3 shows the results of analyses of peat ashes from three different localities. Two to three samples from different depths have been analyzed at the same investigation point.

Lapaneva in Kihniö is part of the Aitoneva area described above. The distance between these investigation sites is $3 \mathrm{~km}$. Both are located in a granite area according to the Prequaternary map of Tampere by Sederholm (30). The sample series from Malmisuo in Otanmäki, which includes samples $3-4$, is taken from a bog located on a granite base. The type of bedrock has been verified there by diamond drillings carried out by the Otanmäki Mining Company. Samples 5-7 are taken from Malmisuo in Otanmäki, only $190 \mathrm{~m}$ from the former site, from a place where, according to diamond drilling, there is a titanium- vanadium- bearing iron ore body surrounded by amphibolite (26). Samples 8-9 from the Varkkasalonräme - a bog in Vimpeli — are from the immediate vicinity of a limestone outcrop in Vimpeli. The bog is fen type pine bog. Its peat varieties, the high $\mathrm{pH}$ values of the peat and the study of Ruostesuo - a bog in Utajärvi - by the present author (28) all indicate that limestone is the basis for Varkkasalonräme.

Table 3. Analyses of peat ashes from bogs located on different kinds of bedrock.

\begin{tabular}{|c|c|c|c|c|c|c|c|c|c|c|c|c|c|}
\hline \multirow[t]{2}{*}{ No } & \multirow{2}{*}{$\begin{array}{l}\text { Peat kind } \\
\text { and } \\
\text { humification }\end{array}$} & \multirow{2}{*}{$\begin{array}{c}\text { Depth } \\
\text { m }\end{array}$} & \multirow{2}{*}{$\mathrm{pH}$} & \multirow{2}{*}{$\begin{array}{c}\text { Ash } \\
\%\end{array}$} & \multicolumn{2}{|c|}{$\begin{array}{c}\mathrm{SiO}_{2} \\
\% \\
\end{array}$} & \multicolumn{2}{|c|}{$\begin{array}{c}\mathrm{Al}_{2} \mathrm{O}_{3} \\
\% \\
\end{array}$} & \multicolumn{2}{|c|}{$\begin{array}{c}\mathrm{Fe}_{2} \mathrm{O}_{3} \\
\% \\
\%\end{array}$} & \multicolumn{2}{|c|}{$\begin{array}{c}\mathrm{CaO} \\
\% \\
\end{array}$} & \\
\hline & & & & & 1 & 2 & 1 & 2 & 1 & 2 & 1 & 2 & \\
\hline 1 & $\mathrm{~S} \mathrm{H}_{3}$ & $0-0.5$ & 3.2 & 2.31 & 63.7 & 1.465 & 6.9 & 0.159 & 6.0 & 0.138 & 8.0 & 0.184 & Lapaneva, \\
\hline 2 & $\mathrm{CS} \mathrm{H}_{9}$ & $1.8-2.0$ & 4.4 & 2.02 & 39.5 & 0.798 & 18.9 & 0.378 & 17.6 & 0.355 & 17.1 & 0.342 & Kihniö \\
\hline 3 & $\mathrm{NS} \mathrm{H}_{3}$ & $0-0.1$ & 3.2 & 3.98 & 47.8 & 1.912 & 7.5 & 0.300 & 15.9 & 0.636 & 13.6 & 0.544 & Malmisuo, Otan- \\
\hline 4 & LS $\mathrm{H}_{7}$ & $0.2-0.4$ & 3.7 & 4.60 & 58.0 & 2.668 & 16.3 & 0.500 & 9.5 & 0.437 & 5.2 & 0.239 & mäki, Vuolijoki \\
\hline 5 & $\mathrm{SC} \mathrm{H}_{3}$ & $0-0.1$ & 6.0 & 35.0 & 9.7 & 3.395 & 3.0 & 1.050 & 75.8 & 26.530 & 4.5 & 1.575 & Malmisuo, \\
\hline 6 & $\mathrm{SC} \mathrm{H}_{7}$ & $0.5-0.7$ & 5.5 & 9.75 & 34.5 & 3.264 & 21.5 & 2.296 & 21.1 & 2.057 & 3.9 & 0.380 & Otanmäki \\
\hline 7 & LC $\mathrm{H}_{s}$ & $1.2-1.5$ & 5.6 & 8.1 & 28.5 & 2.309 & 35.1 & 2.843 & 17.7 & 1.434 & 6.1 & 0.494 & $"$ \\
\hline 8 & Eutr. SC $\mathrm{H}_{2}$ & $0-0.1$ & 7.2 & 7.3 & 7.6 & 0.559 & 2.4 & 0.175 & 4.2 & 0.307 & 43.3 & 3.161 & Varkkasalonräme, \\
\hline 9 & $\Rightarrow \quad \mathrm{SC} \mathrm{H}_{6}$ & $0.5-0.6$ & 6.6 & 7.2 & 3.5 & 0.252 & 2.0 & 0.144 & 4.0 & 0.288 & 48.7 & 3.506 & Vimpeli \\
\hline
\end{tabular}

There are acid S- and S-dominated peats in the granite areas. Their ash contents and $\mathrm{pH}$ values are lower than those of the other samples presented in the Table. Both values decrease upwards in these profiles, contrarily to those of the others. 
The $\mathrm{SiO}_{2}$-content is highest in the ash of acid peats. In the dry-matter of peat again it is highest in samples 5-7. The $\mathrm{SiO}_{2}$ content in the peats of limestone areas is distinctly less. The $\mathrm{Al}_{2} \mathrm{O}_{3}$ content is highest in specimens 6 and 7 from Malmisuo, in others differences are small. $\mathrm{Fe}_{2} \mathrm{O}_{3}$ is most abundant in the uppermost sample (5) taken from the series above the Malmisuo iron ore. In the dry-matter of peat in this sample the $\mathrm{Fe}_{2} \mathrm{O}_{3}$ content is $40-200$ times as high as in the two other bogs of Table 3. The contents increase from the bottom upwards. The results of the analysis from Varkkasalonräme deviate markedly from the others due to their high $\mathrm{pH}$ and $\mathrm{CaO}$ contents. They indicate the presence of limestone in the same way as samples 5-7 from Malmisuo show evidence of iron ore under the bog.

The author (24) has earlier undertaken an analysis of trace elements from Varkkasalonräme. It revealed amongst other things that the amounts of copper, zinc and cobalt in peat ash were too low to be determined by the analysis method used. The samples from Malmisuo (26) contained scanty traces of molybdenum in addition to the elements mentioned above.

Table 4. Copper and molybdenum contents of peats on lines $\mathrm{c}-\mathrm{d}$ and R 11, in Riivijänkä, Ylitornio. $1=$ in peat ash, $2=$ in dry-matter of peat.

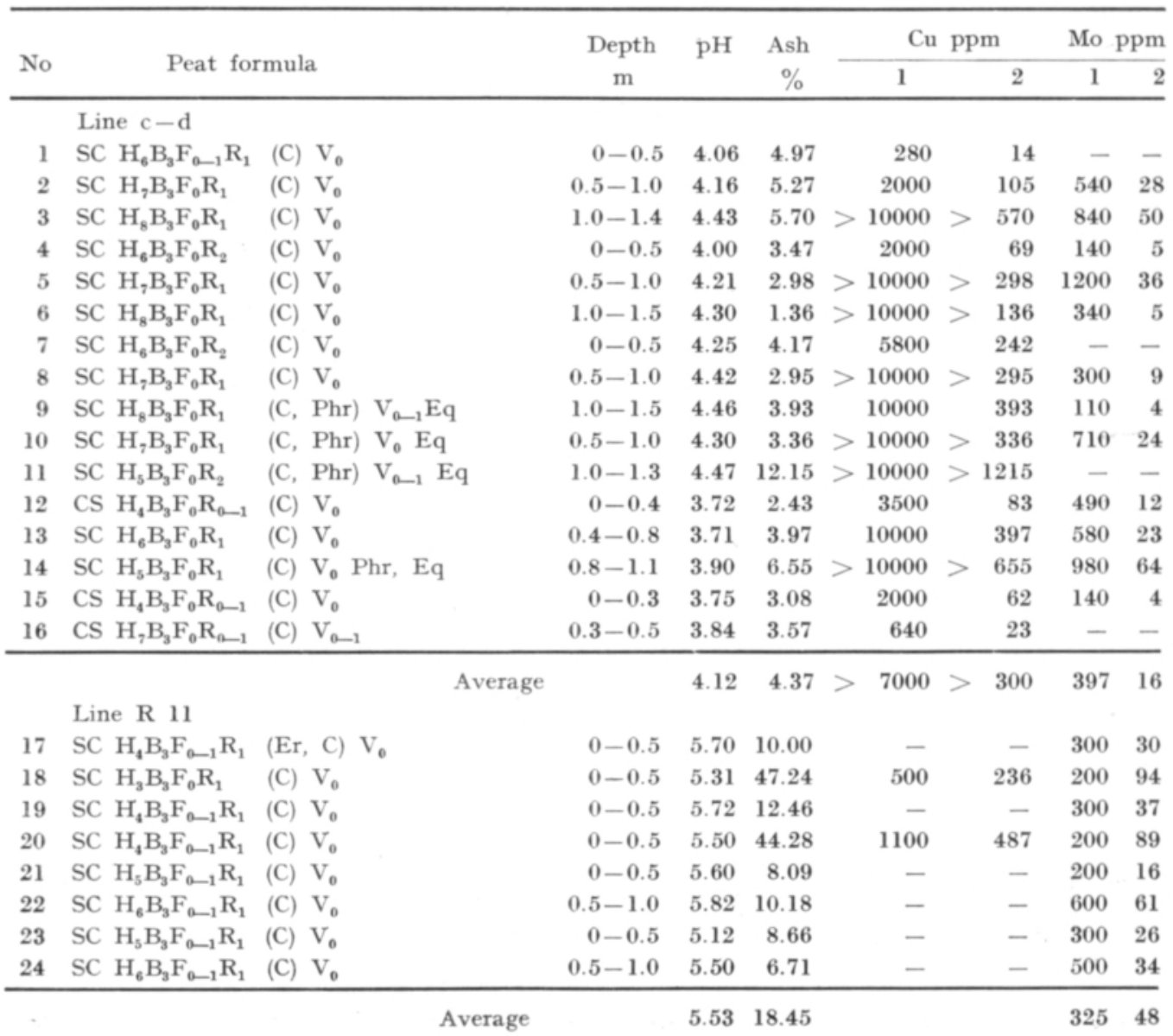


Results from the Riivijänkä area in Ylitornio are presented in Table 4. According to Yletyinen (39) the deep drillings carried out by the Ore Department of the Geological Survey have revealed considerable amounts of molybdenite in a $900 \mathrm{~m}$ long zone in the bedrock underlying the bog land. $\mathrm{MoS}_{2}$ occurs there as short dikes and lenses. In some places pyrite has also been met with as an impregnation.

The author has studied trace element contents of ore profile samples across the above zone. Further material was derived from other parts of the bog region. Among other elements, copper and molybdenum were spectrographically analyzed from peat ashes. Pertinent results from two investigation lines are shown in Table 4. Line $\mathrm{c}-\mathrm{d}$ totalled $225 \mathrm{~m}$ in length but in this connection results from a section only $125 \mathrm{~m}$ long are given (samples $1-16$ ) because molybdenum, and particularly copper, were found there in remarkably higher proportions than (a) along other parts of the line; (b) on other lines in Riivijänkä; or (c) in Finnish peats in general. Later hole R 33 was drilled close to the investigation line, leading to the discovery of molybdenite and pyrite as dikes and intrusions in the bedrock (39). Similarly, results from line R 11 (samples $17-24$ ) are taken only from a 200 m.-long section of this 560-m. long line. The line was located on the bog in the direction of the drill hole, R 11. On the former line the thickness of peat was mostly $1.5 \mathrm{~m}$, on the latter $0.5-1.0 \mathrm{~m}$. At hole $\mathrm{R} 33$ the thickness of overburden was about $5 \mathrm{~m}$, and at R 11 about $2.5 \mathrm{~m}$ above bedrock. Both lines were comprised of (with a few exceptions) SC peat whose humification degree was $3-8$. The $\mathrm{pH}$ values and ash contents were markedly higher in the latter profile than in the former. Investigation points on line $\mathrm{c}-\mathrm{d}$ were spaced at $25 \mathrm{~m}$ distances. On line $\mathrm{R} 11$ they were spaced at the same distance, but at distances of 50 metres at one end of the line.

Several specimens from line $\mathrm{c}-\mathrm{d}$ contained over $10000 \mathrm{ppm}(=>1 \%)$ copper in the peat ash. Such values are unusually high compared with the others the author has found elsewhere in Finland. The highest value met with was more than $1.2 \mathrm{~kg}$ in a ton of dry peat. On this line copper comprises $>7000 \mathrm{ppm}$ of peat ash and $>300 \mathrm{mg} / \mathrm{kg}$ in the dry-matter of peat.

On line R 11 copper was found only in a couple of samples as amounts detectable by the methods used, and must consequently be sporadic on this line. On this line copper was also found to be rather scarce in deep drillings (39). The copper content in most of the investigated lines at Riivijänkä was as low, although values rising noticeably above the average, or $1000-5000 \mathrm{ppm}$, are not too rare. Copper abounds in peat ashes particularly in the southern and western parts of the $\mathrm{MoS}_{2}$ zone verified in the area. At the same sites the highest copper contents have also been found in bedrock revealed during diamond drilling (39).

Molybdenum occurs in peat samples from many profiles at Riivijänkä most often as $10-200 \mathrm{ppm}$ of peat ash, but values less than $10 \mathrm{ppm}$ are fairly frequent. They represent the molybdenum background in the bog area in question. In the part of line $\mathrm{c}-\mathrm{d}$ presented in the table Mo-contents in the peat ash are in some samples $<10 \mathrm{ppm}$. Otherwise the contents are remarkably high, $-110-1200 \mathrm{ppm}$. The average on this line is $397 \mathrm{ppm}$ of peat ash. In analysable cases molybdenum forms $4-64 \mathrm{mg} / \mathrm{kg}$ and on average $16 \mathrm{mg} / \mathrm{kg}$ of the dry-matter of peat. 
On the line R 11 molybdenum forms $200-600 \mathrm{ppm}$ and on average $325 \mathrm{ppm}$ of ash content. Calculated as a proportion of the dry-matter of peat the values are $16-94 \mathrm{mg}$, on average $48 \mathrm{mg} / \mathrm{kg}$ or three times as high as on in line $\mathrm{c}-\mathrm{d}$.

Yletyinen found $\mathrm{MoS}_{2}$ veins in the Kahvikallio outcrop in the Riivikallio area. One peat sample close to that locality contained molybdenum in the proportions $>2000 \mathrm{ppm}$ in ash and $>112 \mathrm{mg} / \mathrm{kg}$ in dry peat.

Table 5

\begin{tabular}{|c|c|c|c|c|}
\hline \multirow{2}{*}{$\begin{array}{c}\text { Depth } \\
\mathrm{m}\end{array}$} & \multicolumn{2}{|c|}{$\mathrm{Cu}$ ppm } & \multicolumn{2}{|c|}{ Mo ppm } \\
\hline & 1 & 2 & 1 & 2 \\
\hline $0-0.5$ & 2716 & 94 & 154 & 4 \\
\hline $0.5-1.0$ & 7107 & 244 & 555 & 20 \\
\hline $1.0-1.5$ & 10000 & 594 & 454 & 25 \\
\hline
\end{tabular}

Table 5 shows copper and molybdenum contents at different depths in the peat layer at Riivijänkä. It appears that both increase from the surface towards the bottom. The peat layer is generally thin on line R 11, but at some points, samples $21,22,23$, and 24 in Table 4 , it is one metre thick. These molybdenum contents are also higher at the bottom than in the surface peat.

Earlier the author (29) had found molybdenum to be most abundant in the surface samples from the Susineva bog at Rautio. Under this bog Suomen Malmi Oy (the Finnish Ore Company) has found molybdenite in the bedrock by means of deep drilling. In places molybdenum forms a proportion of $1300-2000 \mathrm{ppm}$ in peat ash and $41-65 \mathrm{mg} / \mathrm{kg}$ in dry peat. Most of the corresponding values are $<10-300 \mathrm{ppm}$ and $<1-14 \mathrm{mg} / \mathrm{kg}$ in the peat. The copper content in the Susineva peat ashes remains usually under $300 \mathrm{ppm}$. A noteworthy peculiarity is the presence of $50-1000$ ppm wolfram in the peat ash. It seems to coincide with occurrences of molybdenum. The author has seldom met wolfram exceeding $50 \mathrm{ppm}$ in content in peat in Finland. That content is the lowest measurable by the method of analysis used.

Table 6. Luetsuo, Vuolijoki. Phosphorus and sulphur content in drymatter of peat.

\begin{tabular}{|c|c|c|c|c|c|c|c|c|c|c|}
\hline $\begin{array}{c}\text { Depth } \\
\text { m }\end{array}$ & $\begin{array}{l}\text { Peat } \\
\text { kind }\end{array}$ & $\mathrm{pH}$ & $\begin{array}{l}\text { Ash } \\
\%\end{array}$ & $\begin{array}{c}\mathrm{P} \\
\%\end{array}$ & $\begin{array}{c}\mathrm{S} \\
\%\end{array}$ & $\begin{array}{l}\text { Peat } \\
\text { kind }\end{array}$ & $\mathrm{pH}$ & $\begin{array}{l}\text { Ash } \\
\%\end{array}$ & $\begin{array}{l}\mathrm{P} \\
\%\end{array}$ & $\begin{array}{l}\mathrm{S} \\
\%\end{array}$ \\
\hline $0-0.5$ & $\mathrm{CS} \mathrm{H}_{4}$ & 4.5 & 0.90 & 0.084 & 0.22 & $\mathrm{SC} \mathrm{H}_{3}$ & 4.6 & 1.44 & 0.152 & 0.24 \\
\hline $0.5-1.0$ & $\mathrm{SC} \mathrm{H}_{5}$ & 4.8 & 0.81 & 0.088 & 0.22 & $\mathrm{SC} \mathrm{H}_{5}$ & 5.1 & 1.76 & 0.127 & 0.23 \\
\hline $1.0-1.5$ & $\mathrm{SC} \mathrm{H}_{5}$ & 4.8 & 1.11 & 0.089 & 0.21 & SC $\mathrm{H}_{6}$ & 5.2 & 1.56 & 0.139 & 0.26 \\
\hline $1.5-2.0$ & $\mathrm{SC} \mathrm{H}_{7}$ & 5.0 & 1.11 & 0.102 & 0.21 & $\mathrm{SC} \mathrm{H}_{7}$ & 5.3 & 2.19 & 0.171 & 0.16 \\
\hline $2.0-2.5$ & SC $\mathrm{H}_{8}$ & 5.2 & 2.12 & 0.109 & 0.28 & SC $\mathrm{H}_{8}$ & 5.4 & 2.83 & 0.173 & 0.27 \\
\hline $2.5-3.0$ & $\mathrm{SC} \mathrm{H}_{8}$ & 5.1 & 2.34 & 0.088 & 0.28 & SC $\mathrm{H}_{8}$ & 5.5 & 3.01 & 0.146 & 0.20 \\
\hline $3.0-3.5$ & $\mathrm{SC} \mathrm{H}_{8}$ & 5.2 & 2.47 & 0.099 & 0.42 & SC $\mathrm{H}_{9}$ & 5.5 & 5.84 & 0.128 & 0.19 \\
\hline $3.5-4.0$ & SC $\mathrm{H}_{8}$ & 5.2 & 5.01 & 0.090 & 0.41 & - & - & - & - & - \\
\hline & & & & & & & & 2.66 & 0.148 & 0.22 \\
\hline
\end{tabular}


In Table 6 figures from two bog profiles from Luetsuo in Vuolijoki are presented. The bog lies some $3 \mathrm{~km}$ west of the Otanmäki mining district. Profiles were taken about $1 \mathrm{~km}$ from each other. Peat varieties and humification are very much alike in both. $\mathrm{pH}$ values and ash contents are slightly higher in the latter profile, and both values decrease from the bottom towards the surface. The results given in Table 6 show that the phosphorus content in the specimen on the right of the table is on average $38 \%$ higher than that in the other sample. Differences are distinct throughout the profiles. In both profiles the highest P-contents occur at a depth of 1.5 to 2.5 metres.

Sulphur contents are of the same order of magnitude in the Luetsuo profiles. Only the two lowest samples in the profile on the left have high contents deviating from the others. In the same profile, contents are found to decrease from the bottom towards the surface, but the other profile displays equal values at all depths.

Table 7 contains information about proportions of antimony in bedrock and peat ashes seldom found in Finland registered at Törnävä in the Seinäjoki area. According to PÄÄKKöNEN (22) antimonite has been observed in the outcrop at this site, and peat samples were taken some $10 \mathrm{~m}$ away from a bog by the side of a

Table 7. Antimony content of peat, Törnävä, Seinäjoki. $\mathbf{1}=$ in peat ash, $\mathbf{2}=$ in dry-matter of peat

\begin{tabular}{|c|c|c|c|c|}
\hline \multirow{2}{*}{\multicolumn{2}{|c|}{$\begin{array}{c}\text { Depth } \\
\mathrm{cm}\end{array}$}} & \multirow{2}{*}{$\begin{array}{c}\text { Ash } \\
\%\end{array}$} & \multicolumn{2}{|c|}{ Sb ppm } \\
\hline & & & 1 & 2 \\
\hline 0 & -25 & 61.48 & 600 & 368 \\
\hline 25 & -50 & 34.55 & 1500 & 518 \\
\hline 50 & -75 & 76.28 & 300 & 229 \\
\hline 0 & -25 & 27.59 & 2500 & 690 \\
\hline 25 & -50 & 30.78 & 4000 & 1231 \\
\hline 50 & -75 & 35.06 & 4000 & 1402 \\
\hline 0 & -25 & 25.03 & 4000 & 1001 \\
\hline 25 & -50 & 28.28 & 4500 & 1273 \\
\hline 50 & -75 & 39.90 & 1500 & 584 \\
\hline & erage & 39.72 & 2545 & 810 \\
\hline
\end{tabular}

brook. The brook has transported much mineral particles to the bog which is reflected in the high ash contents of the samples. Sampling points lie $5 \mathrm{~m}$ apart. The thickness of peat is $75 \mathrm{~cm}$ and three samples were taken at each point. Investigation shows that a high ash content lowers antimony contents and at the same time renders more difficult the comparison between samples taken at different depths. The middle sample series where ash occurs evenly in the entire layer gives the impression that the Sb content increases downwards. Contents are, however, surprisingly high $-300-4500 \mathrm{ppm}$ in ash and $229-1402 \mathrm{mg} / \mathrm{kg}$ in the dry-matter of peat. Some $2 \mathrm{~km}$ SE of the Törnävä site peat samples at Pentinneva in the Seinäjoki area were investigated but they did not reveal any sign of antimony. Neither was antimony 
found in several thousand peat samples from different parts of Finland which the author has studied in the course of years. Pentinneva peats again contain more copper and zinc than those from Aitoneva and both elements are fairly abundant in all the samples studied. Copper forms a proportion of from $400-1800 \mathrm{ppm}$ in ash and $5.7-41.5 \mathrm{mg} / \mathrm{kg}$ in dry peat. Corresponding values for zinc are $200-3000$ ppm and $9.5-72.3 \mathrm{mg} / \mathrm{kg}$. These relatively high values are associated with graphiteand pyrite-bearing black schists met with in diamond drillings (22 and 29) in the Pentinneva area. Samples from the schist area thus differ from the peats of the granite area and the deviation is manifested in higher copper and zinc values.

\section{Comparison of results}

Table 8 shows the results of analyses of the contents of peat from different investigations in Finland, similar to those at Aitoneva. The figures show the most common ranges, and the highest contents in each study are given in parenthesis. The results in the Table are similar. The greatest differences are found in the highest contents. The figures for manganese show marked differences.

Table 8. Ranges and maximum contents of some trace elements in Finnish peats according to different investigators.

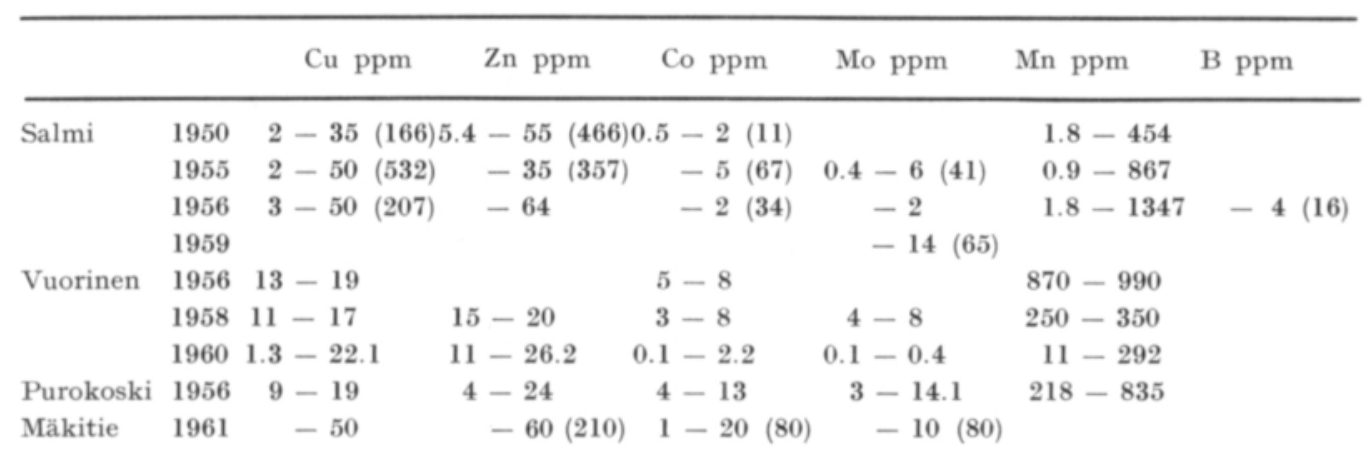

The elements presented in the Table occur in the Aitoneva peat series on average in the following amounts: copper 5.9, zinc less than 40, cobalt 1.06 , molybdenum 1.05 , manganese 67 and boron $3.31 \mathrm{ppm}(\mathrm{mg} / \mathrm{kg})$ of the dry-matter of peat. In Sweden (32) copper forms from 2 to $180 \mathrm{ppm}$ of the dry-matter in peat.

Trace element contents at Aitoneva are similar to those given at the beginning of the ranges given in the Tables. Also the calcium content in Aitoneva peats corresponds to the mean values of Kivinen (6).

The plant nutrient contents of Aitoneva peats belong on the whole to the lowest occurring in peats - some special cases excluded. Variations in different peat varieties also correspond to the values given by different investigators. The lowest amount of plant nutrient is found in Sphagnum peats, the largest in Carex peats. The former are acid and their ash content is generally lower than that of other peats $(4,23,24)$. They are typical peats of granite areas as the author (12) 
earlier verified in places including the area of the Vaasa map sheet. For the sake of comparison mention should be made of some plant nutrient contents in the peat of a bog in the granite area in Scotland as given by BEAR (2): $\mathrm{Cu} \mathrm{10,} \mathrm{Zn}-, \mathrm{Co}<2$, Mn 700, and Mo $<1 \mathrm{ppm}$ of dry-matter of peat. These correspond well to the values derived from Aitoneva, manganese alone being distinctly less in Aitoneva. It can thus be stated that Aitoneva represents a bog, poor in plant nutrient, but typical of a granite area.

Aitoneva peats contain on average $0.47 \%$ of sulphur. The values given by SundGREN and EKMAN (33) $0.11-0.30 \%$ in some bogs in Finland are lower. Sampling point III, with PhrSC peat above a gyttja base, raises the average in Aitoneva. It provides a good example of possible variations within the same bog and at short distances.

As samples $1-4$ of the Table 3 display there is abundant $\mathrm{SiO}_{2}(40-64 \%)$ in the peats of the bogs in granite areas. Samples 1-2 from Lapaneva represent Aitoneva as well. Iron is surprisingly abundant in Aitoneva peats.

Copper and molybdenum contents of the Riivijänkä peats in Ylitornio, in Table 4, are markedly higher than the corresponding contents in Aitoneva and higher than the general level of these trace elements given in Table 8, but some higher contents (in parentheses) are of the same order. In the dry-matter of Riivijänkä peats on the line $\mathrm{c}-\mathrm{d}$, copper occurs on average more than 30 times, and molybdenum 16 times as much as in the Aitoneva peats; along the line R 11 the occurence of molybdenum is 48 times higher than in Aitoneva. Individual samples display still higher differences. Molybdenum contents of peats at Susineva in Rautio are also markedly higher where molybdenite occurs in the bedrock than those verified in Aitoneva peats.

The phosphorus contents in Luetsuo peats are over $2-3$ times higher than in those of Aitoneva, where, however, Sundgren and EkMAN (33) have found values equivalent to those at Luetsuo. This again indicates variations in plant nutrient contents within the same bog. In this case the ash content is high $14.5 \%$. Aitoneva peats contain on average only $3.2 \%$ ash and Luetsuo profiles 1.98 and $2.60 \%$. It has been stated in various connections that the phosphorus content of peats increases with the ash content, and other plant nutrients do likewise.

The high phosphorus content at Luetsuo is partly explained by the SC nature of the peat variety. It has been stated that Sphagnum peats generally contain phosphorus in the least, and Carex peats in the highest, amounts (6). Considerable deviations from this rule exist, however, without satisfactory causal connections. According to KaILA (3) the total phosphorus range in peat is from 190 to $1810 \mathrm{ppm}$. She has also stated that the P-content of S-peat increases downwards and that of C-peats in the opposite direction. Evidently the high phosphorus content of Luetsuo peats at the borders of the ore district is associated with the more than average phosphorus content in the bedrock. The native phosphorus reserve in Finnish peats is generally so scanty that first crops in bog cultivations tend to exhaust it.

The mean sulphur content in Aitoneva peats increases due to profile III and exceeds the Luetsuo values. Some $5-7 \mathrm{~km} \mathrm{~S}$ of the Otanmäki ore district the author 
has found in a couple of samples at a depth of $4-4.5 \mathrm{~m}$ in two peat profiles in Isosuo (the large bog at Ryynäsenjärvi) $0.86-0.96$ and $1.2-1.74 \% \mathrm{~S}$, values which are markedly higher than those given earlier. It is true that in the upper samples values are close to those of Aitoneva and Luetsuo. The peat variety of the Isosuo samples is PhrSC, and there is about one m gyttja underneath. Immediately west of the highest hillock at Otanmäki, in the $2.5 \mathrm{~m}$ thick peat layer of Vehkasuo the average of five samples is $0.82 \%$ sulphur with ranges $0.74-0.91 \%$. At a site $500 \mathrm{~m}$ from the above-mentioned hillock the corresponding values are markedly lower $0.4 \%$ on average, ranging from 0.1 to $0.73 \% \mathrm{~S}$ in the dry-matter of peat. In the former case there is PhrCS-peat with ash content $10.8-18.7 \%$ and $\mathrm{pH} 5.0-5.2$. The latter profile comprises S-peat uppermost, PhrSC-peat below, and has an ash content of 1.8 to $5.6 \%$ and a pH content of 3.6 to 5.3 . In both cases $10 \mathrm{~cm}$ of gyttja underlies the peat, on a bed of sand.

Apparently the high sulphur content in the peat layers near Otanmäki is caused by local sulphur concentrations in the bedrock. KIVInen (5) also regards the high sulphur content of the sulphate soils widely met with in the coastal area of Ostrobothnia as being originally derived from the sulphur sources in the bedrock. Sulphate soils are mainly located in the gyttja areas of the Littorina Sea with abundant organic remnants and sulphur. PURokoski (15) has studied their distribution and stated that sulphate soils border the Finnish sea coast in a zone of varying breadth. Their upper limit usually remains somewhat below the highest Littorina limit. According to him sulphate soils occur inland in the areas in which the bedrock contains black schists and C-peats contain most abundant quantities of sulphur $(4174 \mathrm{~kg} / \mathrm{ha})$, while the amount is lowest in S-peats $(254 \mathrm{~kg} / \mathrm{ha})$. The highest contents are found in summer, particularly in surface soils, after the longest spells of dry weather, but in spring and in autumn waters wash the sulphur compounds from the earth and drain them away. Sulphate soils contain large quantities of aluminium, calcium and potassium sulphates and chlorides. The amount of salts at the surface is as high as $2.5 \%$ or nearly as high as in the saline soils of Hungary. Therefore a C-peat, used as a soil-improving agent in an area where there was a complete crop failure, gave when measured $\mathrm{pH} 2.5$ (5). The impeding influence of sulphate soils to plants can be decreased with lime.

The high antimony content of the Törnävä peats in Seinäjoki seems unique and nothing comparable has been found in published studies.

Studies and comparisons show that the plant nutrient content of Aitoneva peats is generally scant, peculiar to a granitic bedrock area. As a remarkable proportion of bedrock in Finland includes granite of many kinds results from the Aitoneva peat layer can be considered to represent the normal level of plant nutrients as regards quality and quantity of trace elements. In particular cases the plant nutrient contents in peats vary locally in wide ranges. A common feature of these ranges seems to be their confirmity with the changes in the composition of rocks in the underlying bedrock. This has been confirmed in cases where the quality of bedrock has been specified by diamond drilling. By means of pre-Quaternary, Quaternary and aeromagnetic maps the plant nutrient contents in peat can be considerably pre-estimated. Wrong estimations occur surprisingly often, however, 
especially at the contact zones of rocks. A good example of these is where the Malmisuo ore body of Otanmäki, found in amphibolite, is in contact with granite for some distance. Also the bedrock at Riivijänkä in Ylitornio is provided by granite in which molybdenite occurs as short dykes or pockets, and chalcopyrite as intrusions. They cause remarkably high local Mo and $\mathrm{Cu}$ contents in the peats of the overlying bog, notwithstanding the fact that these elements are too scarce in the bedrock to stimulate mining activity. Similarly Susineva at Rautio lies on a base of granite, but antimony in Seinäjoki occurs in the schist zone. The high lime content of the peats in Varkkasalonräme is easily explained by occurrence of the Vimpeli limestone quarries in the vicinity. The scarcity of phosphorus in Finland's bedrock is the natural cause of the low amounts of phosphorus in peat and its slight variations. Yet the vivianite occurrences met with in the bogs near the Oulu area, whose distribution was studied by Окко (13), must be borne in mind. To some extent they have also been found inland. Among others, the Muhos sediment has been assumed as a source of phosphorus of vivianites $(6,7)$. According to the analyses published by MARmo (8) their phosphorus content is very slight, lower than in the granites of the area. Phosphorus of vivianites is also thought to be derived from the organic matter of gyttja. Changes in sulphur content are basically due to sulphur occurrences in bedrock, but sulphur in organic remains particularly in the area of Littorina sediments is distinctly associated with sulphur-bearing sulphate soil occurrences in the coastal areas.

Peat has a large surface area, and hence its exchange capacity is high. Therefore remarkably large amounts of fertilizers can be added to it - much more than to mineral soils - without causing any damage to plants growing in it. The use of strongly fertilized growth peat, developed by PUUSTJÄRvi (17), is based on these properties of peat.

The trace element quantity in peat is usually small. According to MäkITIE (11) 10 ppm copper may be the lowest limit possible in peat without causing copper deficiency in plants. Very little is known so far about the amounts of trace elements in peat. Most of these elements are, however, readily available to plants - copper and phosphorus excluded. According to Karla (3) the solubility of both organic and inorganic copper decreases rapidly downwards in peat layers. Manganese generally dissolves most easily. According to SILlanPä̈̈ (31) some trace elements dissolve from organic soils in the following order: manganese, cobalt, lead, nickel, zinc, and copper.

As the quality and quantity of trace elements in peats may vary quite surprisingly with changing geological conditions attention should be paid to them in connection with the technical use of bogs. This may influence even the fertilizing of growth peat. Peats may contain compounds poisonous to plants. It is also noteworthy that the contents of most elements increase in a downward direction in peat layers, so that, for example, the quantity of plant nutrient in milled peat increases from year to year. Developments in Finland point to the increasing use and manufacture of growth peat in the near future. The abundant peat reserves in Finland may find a foreign market in the form of growth peat. Possible export presupposes an increase in production and the opening of new workings. As indicated by the 
research carried out it would be most useful to perform an immediate and thorough study of plant nutrients in the areas planned for production, as a beginning for any such scheme.

\section{REFERENCES}

(1) Bannerjee, N. N. \& Colliss, L. A. 1955. Rapid analysis of ash from coal and oil shale by colorimetric methods. Fuel 34: 71-83.

(2) Bear, F. E. 1955. Chemistry of the soil. New York. 1-373.

(3) Kaila, Armi 1956. Phosphorus in various depths of some virgin peat lands. J. Sci. Agric. Soc. Finland 28: 90-104.

(4) KIVINEN, ERKKI 1933. Suokasvien ja niiden kasvualustan kasvinravinnesuhteista. Referat: Untersuchungen über den Gehalt an Pflanzennährstoffen in Moorpflanzen und an ihren Standorten. Acta Agric. Fenn. 27: 1-140.

(5) - - 1944. Aluna- eli sulfaattimaista. Referat: Uber Alun- oder Sulfatboden. J. Sci. Agric. Soc. Finnland. 16:147-161.

(6) - 1948. Suotiede. Porvoo-Helsinki: 1-219.

(7) Kotrlarnen, M. J. 1944. Kasvit erikoislaatuisen substraatin indikaattoreina. Soc. Sci. Fennica 22 B, 6: 1-18.

(8) Marmo, Vladi 1950. Kasveista alustan kallioperän indikaattoreina. Referat: Ubber Pflanzen als Indikatoren von Felsgrund in der Unterlage. Terra 2: 49-61.

(9) Mйкıтıе, Osmo 1956. Om spårelementens förekomst i torvjordar. Ms till NJF:s 10. kongress i Stockholm.

(10) - 1958. Turvemaiden hivenaineista. Koetoiminta ja käytäntö 3 .

(11) - 1961. Eräiden hivenaineiden esiintymisestä viljelysmaissamme. Summary: The occurence of some trace elements in arable soil in Finland. Agrogeol. publ. 78: 1-25.

(12) Mölder, K. \& Salmi, Martti 1955. The general geological map of Finland. B 3 Vaasa. Explanation to the map of superficial deposits. The Geological Survey of Finland: 1-109.

(13) Окко, Vегкко 1944. Vivianiitti ja rautafosfaatti. Maatalous 1: 18-21.

(14) Purokoski, Panvo 1956. Harviala-Turenki. Agrogeologisia karttoja 15. Maatalouskoelaitoksen maatutkimusosasto: $1-76$.

(15) - - 1959. Rannikkoseudun rikkipitoisista maista. - Uber die schwefelhaltigen Böden an den Küste Finlands. Agrogeol. publ. 74: 1-27.

(16) PuUstjãrvi, VILjo 1952. The precipitation of iron in peat soils. Acta Agric. Fenn. 78, $1: 1-72$.

(17) $\quad-1956$. On the cation exchange capacity of peats and on the factor of influence upon its formation. Acta Agric. Scand. 6: 410-449.

(18) - 1960. Turve kasvualustana tomaattiviljelyssä. Summary: Peat as growth base in tomato growing. Suo, 4: 63-67.

(19) - 1960. Turpeen käyttö kurkkumultana. Summary: Peat as growth base for cucumber. Ibid. 5: $77-80$.

(20) - -1960 . Turve neilikan kasvualustana. Summary: Peat as a growth base for carnations. Ibid. 6: $81-88$.

(21) - $\quad$ 1961. Turve krysanteemin kasvualustana. Summary: Peat as substrate for chrysanthemum. Ibid. 3: 46-47.

(22) PĀÃKKönen, V. 1959. Seinäjoen antimoniesiintymä. The Archives of the Geological Survey of Finland.

(23) Salmi, Martit 1949. Physical and chemical peat investigations on the Pinomäensuo bog, SW. Finland. Bull. Comm. géol. Finl. 145: 1-31.

(24) - 1950. Turpeiden hivenaineista. Summary: On trace elements in peat. Geotekn. julk. 51: $1-20$. 
(25) Salmi, Marti 1954. Investigations of the calorific value of peat in Finland. Intern. Peat Symposium Section B 3. Dublin: 1-6.

(26) - - 1955. Prosepcting for bog-covered ore by means of peat investigations. Bull. Comm. géol. Finl. 169: 1-34.

(27) - $\quad$ 1956. Peat and bog plants as indicators of ore minerals in Vihanti ore field in western Finland. Ibid. 175: 1-22.

(28) - - 1958. Soiden peittämän kallioperän vaikutus turpeiden $\mathrm{pH}$-arvoihin. Summary: On the pH-values of peat as affected by the underlying bedrock. Geotekn. julk. 61, 3: 29-39.

(29) - 1959. On peat-chemical prospecting in Finland. Congreso geologico Intern. XX Sessión México, 1956. Exploracion geoquimica II: 243-254.

(30) Sederholm, J. J. 1913. Suomen yleiskartta. Lehti B 2, Tampere. Vuorilajikartan selitys. Geologinen toimisto: 1: 122.

(31) SillanpäÄ, Miкко 1962. On the effect of some soil factors on the solubility of trace elements. Agrogeol. publ. 81: 1-24.

(32) Stenberg, M., Ekman, P., Lundblad, K. \& Svanberg, O. 1949. Om kopparhalt i jord och vegetation och resultat av fleråriga gödslingsförsök i koppar. Kungl. Landbruksakad. Medd. 4: $1-106$.

(33) Sundgren, A. \& Ekman, E. 1960. Pelsonsuon, Jalasjärven ja Kihniön suoalueiden turpeiden kuivatislaustuloksista. Summary: On the dry distillation results from peats of the Pelsonsuo, Jalasjärvi and Kihniō bog areas. Suo 6: 96-100.

(34) VAhtera, ERKKI 1955. Metsänkasvatusta varten ojitettujen soitten ravinnepitoisuuksista. Referat: Uber die Nährstoffgehalte für Wälderziehung entwässerten Moore. Comm. Inst. Forest. Fenniae 45, 4: 1-108.

(35) Vuorinen, Jouko 1956. Finska undersökningar rörande $\mathrm{Mn}, \mathrm{Cu}$ och B. Nord. jordbr. forskn. 38: $199-209$.

(36) - 1957. Hivenravinteista Suomen maaperässä. Koetoiminta ja käytäntö 12.

(37) - 1958. On the amounts of minor elements in Finnish soils. J. Sci. Agric. Soc. Finland $30: 30-35$.

(38) - 1960. Hivenaineista Tampereen-Lempäälän seudun maaperässä. Summary: On the minor element contents of soils in the Tampere-Lempäälä district. Maatalous ja koetoiminta 14: $24-32$.

(39) Yletyinen, Veijo 1956. Selostus Ylitornion Kivilompolon tutkimusalueen malmitutkimuksista. The Archives of the Geological Survey of Finland.

SELOSTUS:

\title{
GEOLOGISTEN TEKIJÖIDEN VAIKUTUKSESTA TURPEIDEN KASVINRAVINNE- PITOISUUTEEN
}

\author{
MartTi Salmi
}

\author{
Geologinen tutkimuslaitos, Otaniemi
}

Tutkimuksessa on käsitelty kahdeksasta suosta (kuva 1) otettujen turvenäytteiden kasvinravinnepitoisuuksia. Lähtöaineistona oli Kihniön Aitonevan kolme turveprofiilia (kuva 2). Näytteistä määritettiin kupari, sinkki, koboltti, molybdeeni, boori, rauta, mangaani, kalsium, fosfori ja rikki. Tulokset esitetään taulukoissa 1 ja 2. Aitoneva sijaitsee kallioperäkartan mukaan laajalla graniittialueella.

Muut tutkimuksen kohteina olleet suot sijaitsevat erilaisilla kivilajialueilla. Eräissä kohteissa suon alla oleva kallioperä sisältää tärkeitä malmimetalleja kuten kuparia, molybdeeniä ja harvinaista 
antimonia. Niiden sijainti ja kivilajien vaihtelu on todettu timanttikairauksilla. Vimpelin kalkkikivialueen läheisyydessä sijaitsevan Varkkasalonrämeen turvenäytteitä on myös analysoitu. Kaikkien näiden soiden analyysituloksia esitetäăn taulukoissa $3-7$. Taulukossa 8 esitetään vertailun vuoksi aikaisemmin julkaistuja tuloksia turpeiden ko kasvinravinteista.

Tutkimukset ovat osoittaneet, että Aitoneva edustaa meillä kasvinravinnepitoisuudeltaan sangen köyhää, mutta tyypillistä graniittialueen suota. Liuskealueen suossa on todettu selvästi runsaammin kuparia ja sinkkiä.

Niissä tutkimuskohteissa, missä soiden alla on kallioperässä tärkeitä malmimetalleja kuten Otanmäen Malmisuon alla rautaa, Ylitornion Riivijängän alla kuparia ja molybdeeniä, Raution Susinevan alla molybdeeniä sekä Seinäjoen Törnävän kohteessa antimonia, on vastaavilla kohdilla turpeissa näitä aineita huomattavasti Aitonevan pohjatasoa runsaammin. Kalkkialueen soissa turpeiden korkea $\mathrm{pH}$ sekä CaO-pitoisuus ovat hyviä kallioperän indikaattoreita. Geologisten tekijöiden ja turpeiden kasvinravinnepitoisuuksien kesken näyttää vallitsevan kiinteä vuorosuhde. Kasvinravinteiden määrä lisäăntyy turvekerrostumassa useimmiten ylhäältä alaspäin mennessä. 